Prof. dr. sc. Refik Ćatić, Pedagoški fakultet Univerziteta u Zenici Mr. sc. Vahdeta Ćatić, Pedagoški fakultet Univerziteta u Zenici

\title{
ISPITIVANJE OBRAZOVNIH EFEKATA STEP BY STEP PROGRAMA
}

Sažetak

Cilj ovog istraživačkog rada bio je pokušati ustanoviti obrazovne učinke programa Step by Step $i$ uporediti ih s učincima klasičnog osnovnoškolskog programa kod učenika IV razreda osnovne škole.

Istraživanje je pokazalo kako nema značajne razlike $u$ obrazovnim efektima između učenika koji nastavu pohađaju po metodologiji usmjerenoj na dijete i učenika koji pohađaju «klasičnu» nastavu iz predmeta Matematika i Priroda i društvo.

Ustanovljene su značajne razlike u zadovoljstvu i pozitivnijem odnosu prema školi učenika koji nastavu pohađaju po metodologiji usmjerenoj na dijete i njihovih roditelja.

Učenici koji nastavu pohađaju po metodologiji usmjerenoj na dijete slobodniji su, vješto komuniciraju poštujući pravila komunikacije, samopouzdaniji su, izražavaju svoje mišljenje, donose odluke, sposobni su za timski rad i uvažavaju različitosti.

Dobiveni rezultati vrlo su ohrabrujući jer, prema viđenjima djece $i$ roditelja, planiranje poučavanja tako da bude prilagođeno djetetovom razvoju $i$ potrebama, uistinu doprinosi stvaranju pozitivnije i stimulirajuće razredno-nastavne klime.

\section{$U V O D$}

Osnovu Step by Step programa čini čvrsto uvjerenje u principe demokratije i vrijednosti inherentne demokratskom načinu življenja. Model Step by Step je osmišljen tako da djeca nauče kako da budu odgovorni sudionici u demokratskom društvu. Razvija im svijest da čitav život predstavlja uzajamnu povezanost. 
Zajednica u kojoj se vodi briga o svakom članu gradi se zajedničkim radom roditelja i škole, razrednih nastavnika koji demonstriraju ljubaznost i praksu razvojnog podučavanja. Očekivanja nastavnika podrazumijevaju pozitivno ponašanje, a ne zahtjeve. Nastavnici uvažavaju nastojanja i sposobnost svakog djeteta da dođe do svog načina učenja.

Idejni okvir Step by Step programa za osnovneškolske ustanove zasnovan je na vjerodostojnom istraživanju, snažnom teoretskom okviru i nastavnoj praksi uspješnih odgajatelja iz cijelog svijeta.

U građenju teoretskih postavki model Step by Step polazi od mnogih ideja. Obuhvaćen je rad Rousseana, Pestalozzija, Froebela i M. Montessori (koji su dugo smatrani utemeljiteljima obrazovanja u ranom djetinjstvu), kao i savremenih modela kao British Infant School (Britanska škola za djecu).

Teorijska polazišta Programa Korak po korak temelje se na spoznajama znanstvene psihologije i pedagogije o optimalnim oblicima učenja i poučavanja u dječijoj dobi. Program obuhvaća temeljne postavke individualnog konstruktivizma (Piaget), socijalnog konstruktivizma (Vigotski), Brunerove spoznaje o važnosti govora za mišljenje, Deweyeve spoznaje o važnosti aktivnosti, spoznaje M. Montessori o razvijanju samostalnosti i samoutjecajnosti putem samostalnog odlučivanja, spoznaje neuroznanosti o razvoju i funkcioniranju ljudskog mozga, kao i postavke razvojno-primjerenog kurikuluma (Bredekamp). Sve te spoznaje o optimalnim uvjetima okoline za razvoj djeteta kao samostalnog mislioca i rješavatelja problema, kao i cjelovitog ljudskog bića, utkane su u ustroj rada u razredu koji se zasniva na sljedećim principima:

1. Razvojno-primjereni postupci koji uzimaju u obzir cjelokupnu ličnost djeteta

2. $\mathrm{Na}$ dijete usmjeren pristup poučavanju, utemeljen na individualizaciji

3. Centri aktivnosti u razredu

4. Porodično sudjelovanje

5. Cjeloživotno stručno usavršavanje i tehnička podrška za učitelje.

Ciljevima Step by Step programa za osnovnoškolske ustanove obuvaćene su intelektualne i socijalne potrebe razvoja djece, odgajanje u odnosu na razvoj ličnosti. Razvojna dob je onaj uzrast na kojem 
dijete djeluje u sferama socijalnog, fizičkog, govornog i spoznajnog i po definiciji se razlikuje od djetetovog hronološkog uzrasta, stvarnog godišta.

U okviru postupka obrazovanja ličnosti djeca će:

- pokazati poštovanje prema drugima slušajući i dajući primjerene odgovore,

- izvještavati u pismenom obliku ili usmeno o omiljenom liku iz stvarnog života,

- sarađivati sa drugima,

- ispoljavati sposobnost oslanjanja na vlastite snage,

- učestvovati na fer i pošten način.

\section{METODOLOŠKI OKVIR ISTRAŽIVANJA}

U našem znanstveno-istraživačkom radu cilj je pokušati ustanoviti obrazovne učinke programa Step by step i uporediti ih s učincima klasičnog osnovnoškolskog programa kod učenika IV razreda osnovne škole.

Imajući u vidu ovako postavljen cilj, u istraživanju smo postavili sljedeće zadatke:

- ispitati i ustanoviti postojanje razlike u obrazovnim efektima programa Step by step i klasičnog osnovnoškolskog programa Matematike i Prirode i društva;

- ispitati i ustanoviti postojanje razlike o odnosu prema školi u stavovovima učenika koji rade po Step by step programu i učenika koji rade po klasičnom osnovnoškolskom programu;

- ispitati i ustanoviti postojanje razlike u stavovovima roditelja o obrazovnim i drugim efektima programa Step by step i klasičnog osnovnoškolskog programa;

- ispitati stavove nastavnika o efektima programa Step by step od klasičnog osnovnoškolskog programa, a koji utječu na njegove bolje obrazovne učinke;

- ispitati stavove menadžmenta škole o eventualnoj razlici $\mathrm{u}$ obrazovnim učincima progarama Step by step i klasičnog osnovnoškolskog programa. 


\section{Metode, tehnike i instrumenti}

Nacrt istraživačkog rada je po svojoj prirodi neeksperimentalan. Kao glavni koristi se deskriptivno-analitički metod. Unutar ovoga metoda koristimo Survey-metod.

U teorijskom dijelu ovog rada koristili smo se i metodom teorijske analize.

Glavne tehnike predviđene istraživanjem su anketiranje i primjena testova - nizova zadataka objektivnog tipa, skala i upitnika.

Anketiranjem su ispitivani stavovi učenika i roditelja o efektima programa Step by step i klasičnog osnovnoškolskog programa. Nizovi zadataka objektivnog tipa su korišteni s ciljem ustanovljivanja obrazovnih efeketa programa Step by step i klasičnog osnovnoškolskog programa iz Matematike i Prirode i društva.

Od istraživačkih instrumenata korišteni su: NZOT za učenike 3. razreda (Matematika), NZOT za učenike 3. razreda (Priroda i društvo), NZOT za učenike 4. razreda (Matematika), NZOT za učenike 4. razreda (Priroda i društvo), Anketni upitnik za učenike, Anketni upitnik za roditelje, Anketni upitnik za nastavnike i Anketni upitnik za menadžment škole (direktor, pomoćnik direktora i pedagog).

\section{Istraživački uzorak}

Istraživanje je provedeno u četiri razreda u kojima se odvija nastava po metodologiji usmjerenoj na dijete i četiri razreda u kojima se odvija nastava „klasičnog“ tipa. Prvu i drugu grupu sačinjavalo je po 107 učenika. Istraživanjem su obuhvaćena dva treća i dva četvrta razreda koja izvode nastavu usmjerenu na dijete i dva treća i dva četvrta razreda koji nastavu izvode na „klasičan“ način. Škole u kojima se odvijalo istraživanje su: OŠ „Mak Dizdar“ Zenica, OŠ „Edhem Mulabdić“ Zenica, OŠ „Huso Hodžić“ Tešanj i OŠ „Novi Grad“ Tuzla.

\section{REZULTATI ISTRAŽIVANJA}

\section{Obrazovni efekti programa Step by step $i$ klasičnog} osnovnoškolskog programa Matematike i Prirode i društva

Tabela 3: Prikaz rezultata deskriptivne statistike za varijable korištene u istraživanju 


\begin{tabular}{|c|r|r|r|r|r|}
\hline Varijable & N & Minimum & Maksimum & $\begin{array}{c}\text { Aritmetička } \\
\text { sredina }\end{array}$ & $\begin{array}{c}\text { Standardna } \\
\text { Devijacija }\end{array}$ \\
\hline $\begin{array}{l}\text { Ocjene iz Matematike } \\
\begin{array}{l}\text { Ocjene iz Prirode i } \\
\text { društva } \\
\text { Valid N (listwise) }\end{array}\end{array}$ & 214 & 1,00 & 5,00 & 3,4720 & 1,21286 \\
214 & 1,00 & 5,00 & 3,6121 & 1,13999 \\
\hline
\end{tabular}

Rezultati istraživanja su pokazali da je aritmetička sredina ocjena iz Matematike $M=3,472$, a standardna devijacija $s d=1,21286$, dok je aritmetička sredina ocjena iz Prirode i društva $M=3,6121$, a standardna devijacija sd=1,13999 (vidi Tabelu 3).

Tabela 1: Prikaz frekvencije ocjena iz Matematike za cijeli uzorak

\begin{tabular}{|c|c|c|}
\hline Ocjene & Freqency & Percent \% \\
\hline 1 & 17 & 7,9 \\
2 & 25 & 11,7 \\
3 & 66 & 30,8 \\
4 & 52 & 24,3 \\
5 & 54 & 25,2 \\
Total & 214 & 100 \\
\hline
\end{tabular}

Iz Tabele 1. vidljivo je da je uspjeh učenika za cijeli uzorak iz Matematike sljedeći: 7,9\% učenika ima ocjenu 1; 11,7\% učenika ocjenu $2 ; 30,8 \%$ učenika $3 ; 24,3 \%$ učenika $4 ; 25,3 \%$ učenika ima ocjenu 5.

Tabela 2: Prikaz frekvencije ocjena iz Prirode i društva za cijeli uzorak

\begin{tabular}{|c|c|c|}
\hline Ocjene & Freqency & Percent \% \\
\hline 1 & 12 & 5,6 \\
2 & 21 & 9,8 \\
3 & 61 & 28,5 \\
4 & 64 & 29,9 \\
5 & 56 & 26,2 \\
Total & 214 & 100 \\
\hline
\end{tabular}

Iz Tabele 2 vidljivo je da je uspjeh učenika za cijeli uzorak iz Matematike sljedeći: 5,6\% učenika ima ocjenu 1; 9,8\% učenika 2; 
$28,5 \%$ učenika $3 ; 29,9 \%$ učenika $4 ; 26,2 \%$ učenika ima ocjenu 5. Iz tabelarnih prikaza 4 i 5 vidljivo je da su učenici postigli bolji uspjeh iz Prirode i društva.

Generalno posmatrano, možemo zaključiti da su u okviru predmeta Matematika bolji rezultati postignuti u nastavi koja se izvodi po programu Step by step. Tu razliku čini posebnom stanje ocjena 1 i 5. Stanje je sljedeće:

- ocjenu 1 ima 7 učenika iz odjeljenja Step by step i 10 iz klasičnog;

- ocjenu 2 ima 11 učenika iz odjeljenja Step by step i 14 iz klasičnog;

- ocjenu 3 ima 32 učenika iz odjeljenja Step by step i 34 iz klasičnog;

- ocjenu 4 ima 23 učenika iz odjeljenja Step by step i 29 iz klasičnog;

- ocjenu 5 ima 34 učenika iz odjeljenja Step by step i 20 iz klasičnog;

Generalno posmatrano, možemo zaključiti da su u okviru predmeta Priroda i društvo bolji rezultati postignuti u nastavi koja se izvodi po programu Step by step. Ta razlika je veća nego u uspjehu iz Matematike. Stanje je sljedeće:

- ocjenu 1 ima 3 učenika iz odjeljenja Step by step i 9 iz klasičnog;

- ocjenu 2 ima 6 učenika iz odjeljenja Step by step i 15 iz klasičnog;

- ocjenu 3 ima 30 učenika iz odjeljenja Step by step i 31 iz klasičnog;

- ocjenu 4 ima 33 učenika iz odjeljenja Step by step i 31 iz klasičnog;

- ocjenu 5 ima 35 učenika iz odjeljenja Step by step i 21 iz klasičnog;

U OŠ ,Mak Dizdar“ u Zenici istraživanjem je obuhvaćen IV 6 razred koji radi po metodologiji usmjerenoj na dijete i IV 5 razred koji radi po klasičnom osnovnoškolskom programu. Rezultati NZOT - a iz Matematike i Prirode i društva grafički su predstaljeni na sljedećoj slici: 

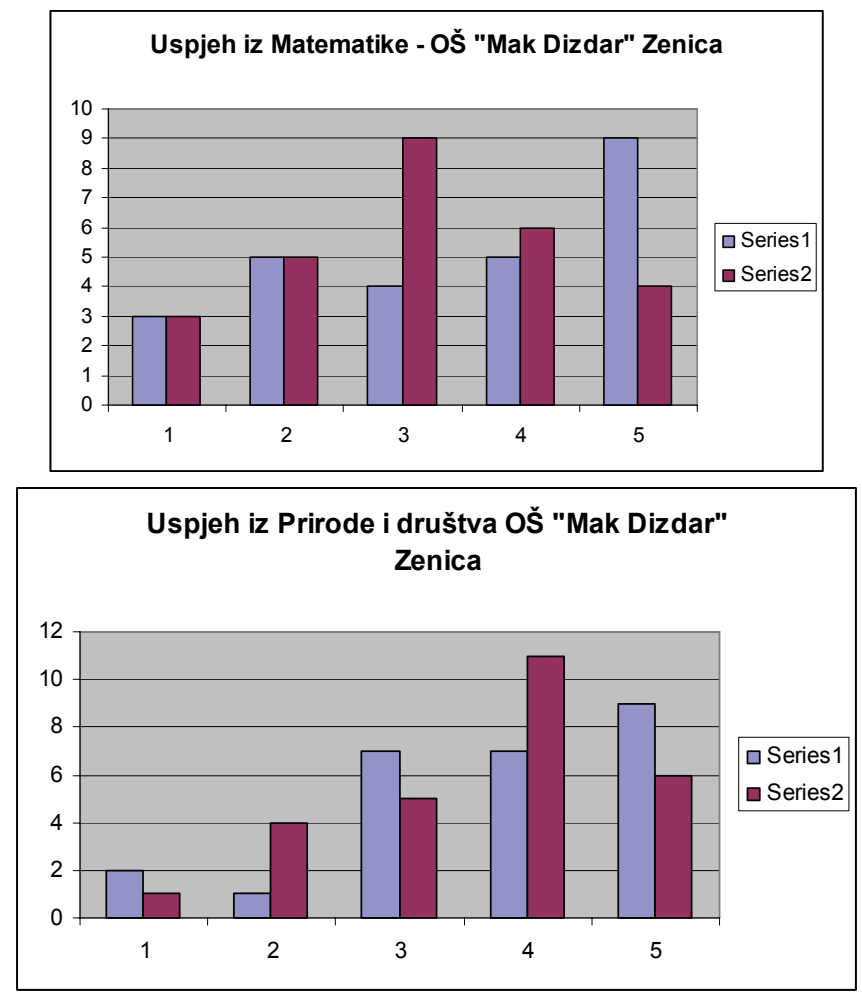

Legenda: 1) SbS razred 2) „Klasični razred“

Slika 1: Obrazovni efekti programa iz Matematike i Prirode i društva Step by step i klasičnog osnovnoškolskog programa u OŠ ,,Mak Dizdar" Zenica

Iz rezultata istraživanja grafički predstavljenih na Slici 1 vidljivo je: učenici koji rade po programu Step by step imaju veći broj petica i iz Prirode i društva i iz Matematike, te manji broj ocjena 2 iz Prirode i društva.

Srednja ocjena iz Matematike kod učenika koji rade po programu Step by step je 3,46, kod učenika koji rade po klasičnom programu 3,11. Srednja ocjena iz Prirode i društva kod učenika koji rade po programu Step by step je 3,77, kod učenika koji rade po klasičnom programu 3,63.

Dakle, bolji su obrazovni efekti programa Step by step od efekata klasičnog osnovnoškolskog programa, ali ne u mjeri u kojoj smo očekivali, naročito ako imamo u vidu postignuti prosjek ocjena po predmetima. Značajno je istaknuti da su učenici koji rade po 
programu Step by step i iz Prirode i društva i iz Matematike pokazali značajno bolji uspjeh.

U OŠ „Edhem Mulabdićc u Zenici istraživanjem su obuhvaćena dva treća razreda, odjeljenje koje radi po metodologiji usmjerenoj na dijete i odjeljenje koje radi po «klasičnom» programu. Rezultati su grafički predstaljeni na sljedećoj slici:
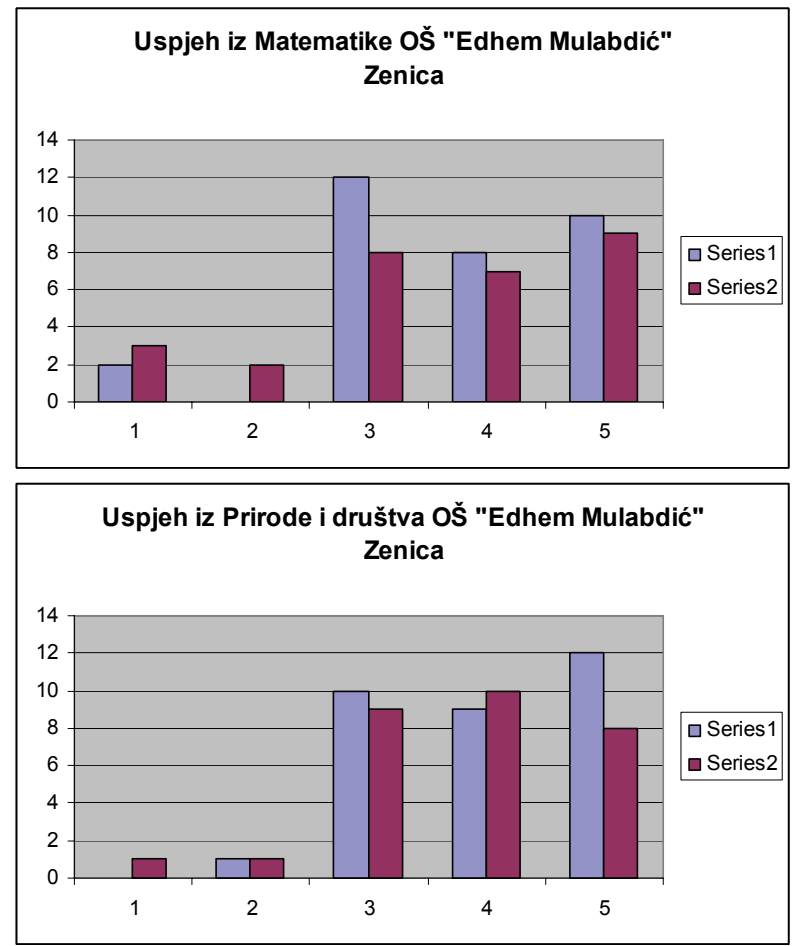

Legenda: 1) SbS razred 2) „Klasični razred““

Slika 2: Obrazovni efekti programa iz Matematike i Prirode i društva Step by step i klasičnog osnovnoškolskog programa u Ǒ́ ,, Edhem Mulabdić" Zenica

Iz rezultata istraživanja grafički predstavljenih na Slici 2 i u Tabeli 9 vidljivo je: učenici koji rade po programu Step by step imaju veći broj ocjena 5 i iz Prirode i društva i iz Matematike, te manji broj ocjena 2 iz Matematike i nemaju ocjene 1 iz Prirode i društva.

Srednja ocjena iz Matematike kod učenika koji rade po programu Step by step je 3,75, kod učenika koji rade po klasičnom programu 3,59. Srednja ocjena iz Prirode i društva kod učenika koji 
rade po programu Step by step je 4,00, kod učenika koji rade po klasičnom programu 3,79.

Dakle, bolji su obrazovni efekti programa Step by step od efekata klasičnog osnovnoškolskog programa, ali ne u mjeri u kojoj smo očekivali, naročito ako imamo u vidu postignuti prosjek ocjena po predmetima.

Pomoćnik direktora OŠ «Edhem Mulabdić» za SbS učenike kaže: «Oni su sigurniji u ono što rade, samostalniji su u radu, znaju kako doći do informacije, kako riješiti problem. Imaju ispoljen smisao za timski rad, određuju sebi cilj i kako doći do njega, racionalno koriste vrijeme. Dobro se služe udžbenikom i drugom literaturom. Skloni su istraživačkom radu. Primijetna je dobra, radna atmosfera. Odgovorni su i imaju osjećaj za konstruktivnu kritiku. U dokazivanju služe se argumentima. Umjesto reproduktivnog učenja do izražaja dolazi kritičko mišljenje i zaključivanje.»

U OŠ „Huso Hodžić“ u Tešnju istraživanjem su obuhvaćena dva četvrta razreda $\mathrm{i}$ to odjeljenje koje radi po metodologiji usmjerenoj na dijete (IV 3) i odjeljenje koje radi po «klasičnom» programu (IV 4). Rezultati su grafički predstaljeni na sljedećoj slici: 

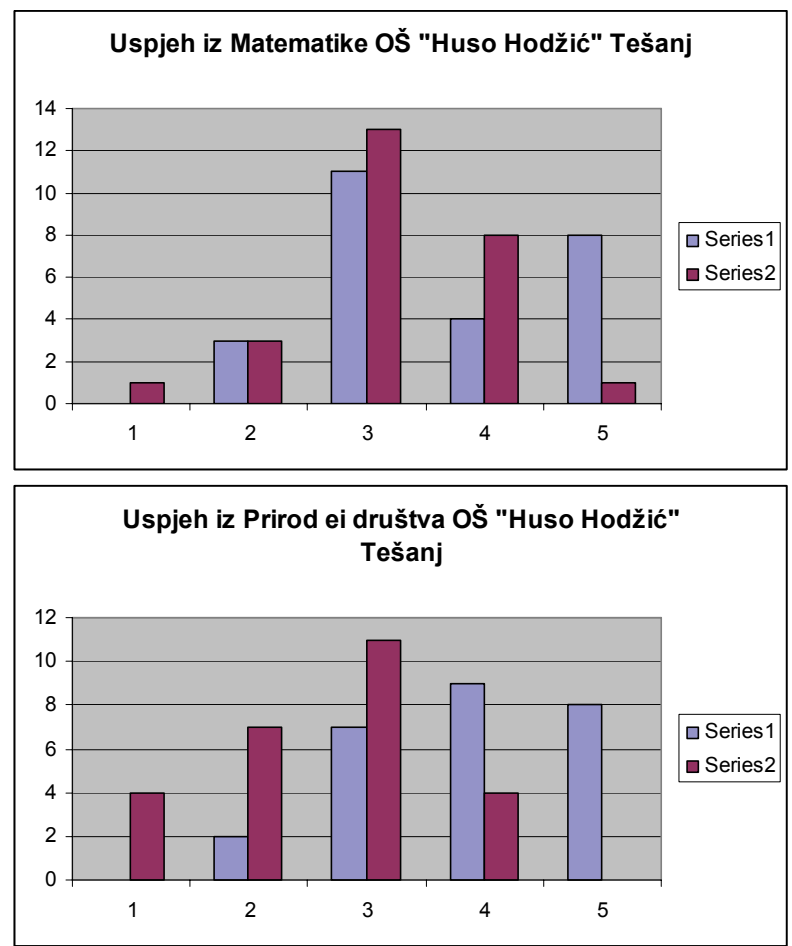

Legenda: 1) SbS razred 2) „Klasični razred“

Slika 3: Obrazovni efekti programa iz Matematike i Prirode i društva Step by step i klasičnog osnovnoškolskog programa u OŠ ,,Huso Hodžić" "Tešanj

Iz rezultata istraživanja grafički predstavljenih na Slici 3 i u Tabeli 10 vidljivo je: učenici koji rade po programu Step by step imaju veći broj ocjena 5 i iz Prirode i društva $i$ iz Matematike, te manji broj ocjena 2 iz Matematike i nemaju ocjene 1 ni iz Prirode i društva ni iz Matematike.

Srednja ocjena iz Matematike kod učenika koji rade po programu Step by step je 3,65, kod učenika koji rade po klasičnom programu 3,19. Srednja ocjena iz Prirode i društva kod učenika koji rade po programu Step by step je 3,88, kod učenika koji rade po klasičnom programu 2,58.

Dakle, vidljivo je da su znatno bolji obrazovni efekti programa Step by step od efekata klasičnog osnovnoškolskog programa, jer je i iz Prirode i društva i iz Matematike pokazali značajno bolji uspjeh. 
Interesantno je kod učenika koji rade po programu Step by step nije bilo ocjene $1 \mathrm{ni}$ iz Matematike ni iz Prirode i društva.

U OŠ „Novi grad“ u Tuzli istraživanjem su obuhvaćena dva treća razreda $\mathrm{i}$ to odjeljenje koje radi po metodologiji usmjerenoj na dijete i odjeljenje koje radi po «klasičnom» programu. Rezultati su grafički predstaljeni na sljedećoj slici:
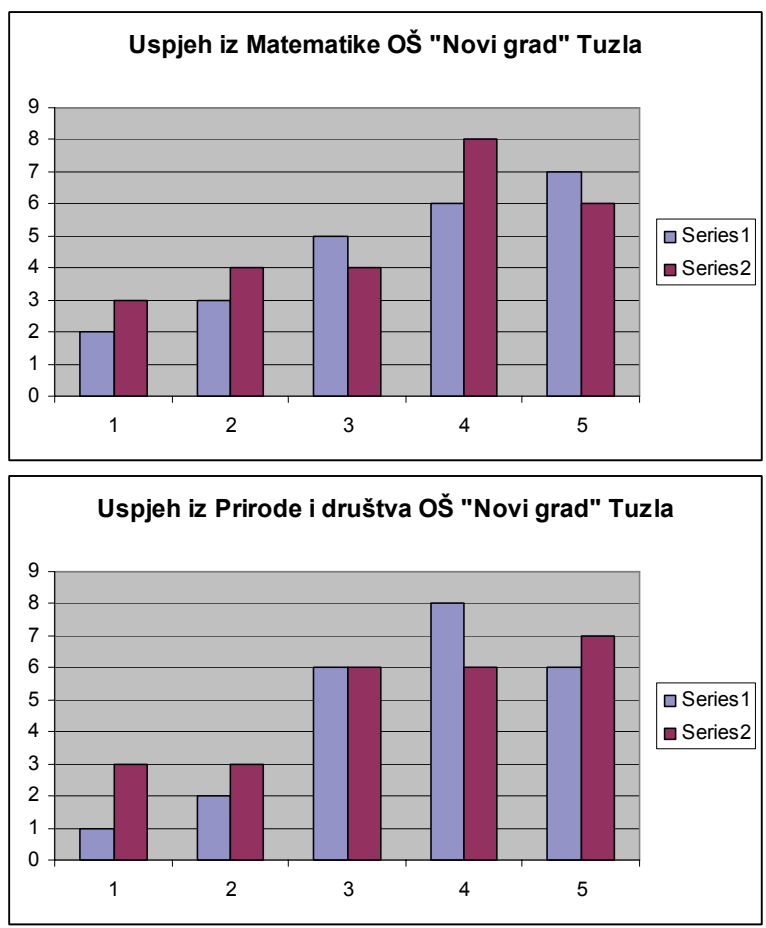

Legenda: 1) SbS razred 2) „Klasični razred“

Slika 4: Obrazovni efekti programa iz Matematike i Prirode i društva Step by step i klasičnog osnovnoškolskog programa u OŠ ,,Novi grad“ Tuzla

Iz rezultata istraživanja grafički predstavljenih na Slici 3 i u Tabeli 11 vidljivo je: učenici koji rade po programu Step by step imaju veći broj ocjena 5 i iz Prirode i društva $i$ iz Matematike, te manji broj ocjena 2 iz Matematike i nemaju ocjene 1 ni iz Prirode i društva ni iz Matematike.

Srednja ocjena iz Matematike kod učenika koji rade po programu Step by step je 3,56, kod učenika koji rade po klasičnom 
programu 3,40. Srednja ocjena iz Prirode i društva kod učenika koji rade po programu Step by step je 3,70, kod učenika koji rade po klasičnom programu 2,44.

Dakle, bolji su obrazovni efekti programa Step by step od efekata klasičnog osnovnoškolskog programa, ali ne u mjeri u kojoj smo očekivali. Značajno je istaknuti da kod učenika koji rade po programu Step by step i iz Prirode i društva i iz Matematike pokazali značajno bolji uspjeh. Interesantno je da je broj ocjena 1 zastupljena $\mathrm{u}$ manjoj mjeri i kod učenika koji rade po programu Step by step.

Rezultati dobiveni na osnovu analize NZOT-ova iz Matematike i Prirode i društva pokazuju da nema neke značajne razlike u znanju između učenika koji pohađaju nastavu po metodologiji usmjerenoj na dijete i učenika koji pohađaju nastavu na „klasičan“ način. Učenici koji rade po programu Step by step pokazali su veći nivo znanja.

Tabela 3: Srednja ocjena iz Matematike i Prirode i društva

\begin{tabular}{|c|c|c|}
\hline Predmet & $\begin{array}{c}\text { Srednja } \\
\text { ocjena } \\
\text { SbS učenika }\end{array}$ & $\begin{array}{c}\text { Srednja ocjena } \\
\text { učenika } \\
\text { «klasike» }\end{array}$ \\
\hline Matematike & 3,52 & 3,34 \\
\hline Prirode i društva & 3,58 & 3,29 \\
\hline
\end{tabular}

Ukoliko pogledamo srednju ocjenu iz Matematike i Prirode i društva (u rezultatima prikazanim u Tabeli 3) učenika koji rade po Step by step programu i učenika koji rade po klasičnom nastavnom programu, možemo zaključiti da je njihov školski uspjeh na sličnom nivou. Iz Matematike učenici koji rade po Step by step programu imaju prosječnu ocjenu 3,52, a učenici koji rade po klasičnom nastavnom programu 3,34. Iz Prirode i društva učenici koji rade po Step by step programu imaju prosječnu ocjenu 3,58, a učenici koji rade po klasičnom nastavnom programu 3,29. Dakle, razlika nije značajna.

$\mathrm{Na}$ osnovu t-testa ustanovljeno je da ne postoji statistički značajna razlika u uspjehu iz Matematike učenika koji rade po programu Step by Step i učenika koji rade po klasičnom programu, jer 
je $\mathrm{t}=1,756$, a $\mathrm{p}=, 081$. Međutim, vidljivo je da postoji statistički značajna razlika u uspjehu iz Proride i društva učenika koji rade po programu Step by Step i učenika koji rade po klasičnom programu, statistički značajno je bolji uspjeh učenika koji rade po programu Step by Step, jer je $\mathrm{t}=3,120$, a $\mathrm{p}=, 002$.

\section{Odnos prema školi učenika koji nastavu pohađaju po Step by step programu i po klasičnom osnovnoškolskom programu}

$\mathrm{Na}$ osnovu podataka dobivenih iz razgovora sa fokus grupom učenika može se zaključiti da su učenici koji nastavu pohađaju po metodologiji usmjerenoj na dijete dosta slobodniji i vještiji $u$ komunikaciji, samopouzdaniji, jasno izražavaju svoje mišljenje i uvažavaju i poštuju druge u grupi.

$\mathrm{Na}$ pitanje ko od njih voli dolaziti svaki dan u školu, u obje grupe djeca su izjavila da vole dolaziti u školu jer se tu druže s prijateljima, sa učiteljicom i uče nove stvari kako bi bili spremni za život koji ih čeka. Nije bilo razlika u odgovoru na drugo i treće pitanje s tim da su SbS učenici mnogo više spominjali učiteljicu za razliku od «klasičnih»učenika.

Uočena je razlika u odgovorima na četvrto pitanje (Šta volite raditi u školi?). Odgovore i jednih i drugih predstavit ću tabelom.

Tabela 4: Stavovi učenika o poželjnim aktivnostima u školi

\begin{tabular}{|l|l|}
\hline \multicolumn{1}{|c|}{ SbS učenici } & \multicolumn{1}{c|}{ Učenici iz «klasike» } \\
\hline $\begin{array}{l}\text { «U školi volim kada radimo u } \\
\text { grupama, jer tada svi zajedno } \\
\text { pokušavamo doći do nekog } \\
\text { rješenja.» }\end{array}$ & «Volim najviše fizičko, kada se igramo.» \\
\hline $\begin{array}{l}\text { «Volim kada slavimo } \\
\text { rođendane.» }\end{array}$ & «Volim crtati.» \\
\hline $\begin{array}{l}\text { «Volim kada se igramo } \\
\text { Tajnih prijatelja.» }\end{array}$ & «Volim se igrati sa svojim drugovima.» \\
\hline $\begin{array}{l}\text { «Volim da radim zanimljive } \\
\text { zadatke iz matematike jer } \\
\text { sam dobar u tome.» }\end{array}$ & $\begin{array}{l}\text { «Volim kada me učiteljica prozove da čitam } \\
\text { jer najbolje čitam u razredu.» }\end{array}$ \\
\hline $\begin{array}{l}\text { «Volim istraživati i } \\
\text { postavljati pitanja.» }\end{array}$ & «Volim matematiku.» \\
\hline
\end{tabular}


Učenici koji nastavu pohađaju na «klasičan « način na peto pitanje (Da li postoje stvari koje biste željeli češće raditi u učionici? Koje su to aktivnosti i zašto biste ih radili češće?) uglavnom su odgovarali da bi voljeli da imaju fizičko, likovno, muzičko svaki dan dok su odgovori SbS učenika slijedeći:

- «Volio bih da nam svaki dan neko dolazi u posjetu.»

- «Voljela bih da češće radimo projekte iz prirode»

- «Volio bih da više radimo matematiku jer mi slabo ide.»

- «Voljela bih da svaki dan radimo lektiru jer su mi ti časovi najzanimljiviji.»

- «Volio bih da svaki dan obilazimo fabrike jer tako najbolje učimo, a i družimo se. U fabrikama uvijek nešto i dobijemo.»

$\mathrm{Na}$ šesto pitanje učenici iz «klasike» su, uglavnom, odgovarali da razgovaraju s roditeljima o ocjenama koje su dobili i da roditelje najviše zanima njihov uspjeh u školi. Učenici SbS kažu da roditeljima ispričaju sve šta su radili u školi jer i oni to moraju znati kako bi im pomogli u nečemu što im slabo ide.

$\mathrm{Na}$ sedmo pitanje učenici iz «klasike» su odgovorili da $\mathrm{u}$ učionici uvijek sjede sa istim drugom ili drugaricom dok su učenici SbS rekli da rade u grupi koja je uvijek različita i da na taj način rade sa svim učenicima u odjeljenju.

$\mathrm{Na}$ osmo pitanje obje grupe su isto odgovorile - svi vole učiti nove stvari u školi.

Zanimljivi su učenički odgovori na deveto pitanje (Da li postoji nešto što vam se ne sviđa $u$ vezi sa školom? Šta biste promijenili?)

Tabela 5: Stavovi učenika o školi

\begin{tabular}{|l|l|}
\hline \multicolumn{1}{|c|}{ SbS učenici } & \multicolumn{1}{|c|}{ Učenici iz «klasike» } \\
\hline $\begin{array}{l}\text { «Volio bih da stariji učenici više paze } \\
\text { na mlađe učenike.» }\end{array}$ & $\begin{array}{l}\text { "Volio bih da i mi imamo } \\
\text { lijepu učionicu.» }\end{array}$ \\
\hline $\begin{array}{l}\text { «Voljela bih da učenici više paze na } \\
\text { zelenilo oko škole.» }\end{array}$ & $\begin{array}{l}\text { "Voljela bih da nema ocjena } \\
. »\end{array}$ \\
\hline «Volio bih da nas učiteljica uči do & $\begin{array}{l}\text { «Volio bih da češće imamo } \\
\text { fizičko.» }\end{array}$ \\
\hline
\end{tabular}


«Volio bih da svake sedmice imamo priredbe za roditelje jer to sami organizujemo.»
«Voljela bih da nemamo puno zadaće»

Iako je ovako jasnim odgovorima učenika komentar suvišan, ističemo da se iz njihovih odgovora vidi slabost klasičnog nastavnog programa i klasičnog načina rada sa učenicima.

Stavovi učenika o čemu uče u školi izneseni su u odgovoru na neše deseto pitanje iz ankete: $\mathrm{O}$ čemu uče u školi?, a prikazani su u Tabeli 6 .

Tabela 6: Stavovi učenika o čemu uče u školi

\begin{tabular}{|c|c|}
\hline SbS učenici & Učenici iz «klasike» \\
\hline $\begin{array}{l}\text { «Učimo o površini tako da znam } \\
\text { izračunati koliko mi treba pločica za } \\
\text { kupatilo.» }\end{array}$ & $\begin{array}{l}\text { «Učimo koje su planine, } \\
\text { rijeke, polja i slično u BiH.» }\end{array}$ \\
\hline $\begin{array}{l}\text { «Naučila sam kako se treba zaštititi } \\
\text { da ne bismo dobili zarazne bolesti.» }\end{array}$ & $\begin{array}{l}\text { «Znamo dijeliti, množiti s } \\
\text { velikim brojevima i raditi } \\
\text { jednačine.» }\end{array}$ \\
\hline $\begin{array}{l}\text { «Ovo je projekat o mom papagaju. } \\
\text { Trebao sam drugovima objasniti } \\
\text { kako vodim brigu o njemu.» }\end{array}$ & $\begin{array}{l}\text { «Učimo o domaćim i divljim } \\
\text { životinjama.» }\end{array}$ \\
\hline $\begin{array}{l}\text { «Znam pisati pjesme. Pročitat ću vam } \\
\text { neke o školi, proljeću, vodi...» }\end{array}$ & «Učimo njemački jezik» \\
\hline $\begin{array}{l}\text { «Učimo o gradovima u BiH . Znam } \\
\text { kroz koje gradove prolazim kad idem } \\
\text { na more.» }\end{array}$ & $\begin{array}{l}\text { «U školi učimo svašta, } \\
\text { računamo, pišemo, čitamo...» }\end{array}$ \\
\hline
\end{tabular}

3. Stavovovi roditelja o obrazovnim i drugim efektima programa Step by step i klasičnog osnovnoškolskog programa

Kako je istaknuto u metodološkom dijelu rada, urađeno je anketiranje roditelja te smo došli do sljedećih zaključaka:

- Roditelji SbS učenika kažu da njihova djeca rado idu u školu i da to znaju jer $u$ školu idu s osmijehom, bez straha i dobrovoljno ostaju tamo i duže nego što treba - «voljeli bi da škola traje čitav dan«. Roditelji «klasike» kažu da učenici vole ići u školu, izuzev kada imaju neke provjere. 
- I jedni i drugi kažu da im djeca govore sve što rade u školi s tim da djeca koja rade po «klasičnom» programu uglavnom govore o tome šta su učili novo, šta su dobili u školi dok SbS djeca govore o načinu rada - kako su učili o nečemu - i traže od roditelja neke podatke koji im trebaju. «Koriste nas kao izvor informacija».

- Na pitanje - U kojim aktivnostima vaše dijete posebno uživa u školi?- roditelji čija djeca pohađaju nastavu po "klasičnom" načinu su uglavnom navodili predmete koje njihova djeca vole dok su roditelji SbS učenika navodili da njihova djeca vole raditi u grupi, da vole kad im neko dolazi u posjetu, vole istraživati, raditi praktične stvari, projekte, zanimljive zadatke iz matematike...

- Najčešći odgovor na pitanje Šta bi promijenili u školama? bio je smanjiti obim NPP i uskladiti gradivo s mogućnostima djece (11,3\% roditelja čija djeca pohađaju klasičnu nastavu).

- Odgovori na pitanje - Koje su važne stvari koje vaše dijete uči u školi?

Tabela 7: Stavovi roditelja o programu po kojem njihova djeca uče

\begin{tabular}{|l|l|}
\hline Roditelji SbS učenika & $\begin{array}{l}\text { Roditelji čija djeca } \\
\text { pohađaju «klasičnu « } \\
\text { nastavu }\end{array}$ \\
\hline $\begin{array}{l}\text { «Uče da su svi jednaki i da svi imaju ista } \\
\text { prava.» }\end{array}$ & $\begin{array}{l}\text { «Bitna je socijalizacija, } \\
\text { znanje koje usvoje jer će im } \\
\text { trebati za dalje školovanje.» }\end{array}$ \\
\hline $\begin{array}{l}\text { «Uče kako trebaju jedni drugima } \\
\text { pomagati.» }\end{array}$ & $\begin{array}{l}\text { «Uče kako da budu dobri } \\
\text { drugovi, da pomažu drugu.» }\end{array}$ \\
\hline «Uče se timskom radu što će im dobro & $\begin{array}{l}\text { «Uče se disciplini, } \\
\text { poštivanju.» }\end{array}$ \\
\hline $\begin{array}{l}\text { «Uči kad odrastu.» se samostalnosti, iznošenju } \\
\text { vlastitog mišljenja, pravilnom }\end{array}$ & $\begin{array}{l}\text { «Najvažnija je matematika i } \\
\text { bosanski jezik jer te } \\
\text { premuniciranju.» }\end{array}$ \\
$\begin{array}{l}\text { predmete imaju u 5. razrednjoj školi. Trebaju } \\
\text { imati dobar temelj.» }\end{array}$ \\
\hline
\end{tabular}


$\mathrm{Na}$ osmo pitanje roditelji djece iz "klasične" nastave odgovarali su da djeca ne uče u školi donošenje odluka, uče se kritičkom mišljenju, samostalnosti i uvažavanju drugih, ali nisu mogli dati primjere za to.

Roditelji učenika koji rade po programu Step by step na osmo pitanje odgovaraju na sljedeći način:

- «Djeca uče donositi odluke, vidio sam kada sama odlučuju na koji način će predstaviti zadatak, ko će šta raditi u grupi i sl.»

- «Učestvuju u donošenju pravila ponašanja u razredu, diskutuju o problemima, daju svoje prijedloge.»

- «Učenici slobodno iznose svoje mišljenje, svoje stavove.»

- «Samostalno radi zadatke kod kuće, traži podatke po knjigama, novinama, internetu.»

- «Uvažavaju jedni druge, nemaju predrasuda, druže se sa svima.»

Upoređujući svoje školovanje sa školovanjem svoje djece, roditelji iz «klasične« nastave tvrde da je razlika najočitija u NPP koji je sada dosta teži nego kada su oni išli u školu, dok roditelji SbS učenika uočavaju razlike i tvrde da je u njihovo vrijeme školovanje bilo obaveza koja se mora obaviti, a sada je školovanje izazovno i veselo iskustvo. Učenici su prije primali informacije koje im prenosi učitelj, a sada učenici su aktivno uključeni u rješavanje problema i planiranje aktivnosti, rade u paru ili grupi. Sada učitelji i djeca zajedno postavljaju pravila ponašanja koja naglašavaju ličnu odgovornost, dok je prije učitelj bio odgovoran za ponašanje i kontrolisao ga svojim autoritetom.

Pitanje na koji način roditelji sarađuju s učiteljem/icom školom otkrilo je kako nema razlika među skupinama u klasičnim aktivnostima kao što su odlazak na informacije i roditeljski sastanak. Razlike se ogledaju u tome što roditelji $\mathrm{SbS}$ učenika sarađuju i na druge načine kao što su: pratnja na izletu ili posjetama, pomoć $u$ organizovanju priredbi, sudjelovanje u nastavi, gostovanje u razredu, izrada plakata za pano, učešće na radionicama, držanje...

Roditelji i prve i druge skupine smatraju da su dobrodošli u učionicu svog djeteta, učitelj/ica ih poštuje i uvažava njihovo mišljenje. 
Općenito, roditelji su zadovoljni obrazovanjem svoje djece. Veće zadovoljstvo napretkom svoje djece pokazali su roditelji $\mathrm{SbS}$ učenika.

\section{Stavovovi nastavnika o programu Step by step u odnosu na klasični osnovnoškolski program}

Budući da su anketirani nastavnici radili po klasičnom programu a sada rade po metodologiji usmjerenoj na dijete, interesirali su nas stavovi nastavnika o eventualnim promjenama koje su nastale otkako primjenjuju metodologiju usmjerenu na dijete. Najčešći odgovori nastavnika su bili:

- Više analiziram svoj rad (samorefleksnija sam) i sigurnija u sebe kao učitelja.

- Uživam u svom radu i više sarađujem s drugim nastavnicima u svojoj školi.

- Bolje razumijem kako da sadržaje podučavanja povežem i učinim relevantnijim za život djeteta.

- Bolje sarađujem s roditeljima.

$\mathrm{Na}$ pitanje u čemu se ogledaju razlike u obrazovnim efektima

SbS programa i klasičnog programa te koji elementi čine ta dva programa različitim najčešći odgovori nastavnika su:

- Djeca sada u mojoj učionici rade kooperativnije, samostalnija su i sposobnija za rješavanje problema.

- Djeca iz SbS odjeljenja više poštuju one koji su drugačiji od njih.

- Roditelji su sada mnogo spremniji da razgovaraju sa mnom i rado učestvuju u aktivnostima u učionici, a djeca su ponosna na njih.

- Djeca su radoznalija, više pitaju, uživaju u radu i postižu bolje rezultate.

- Učenici su slobodniji u komunikaciji, poštuju donesena pravila. Prije je ta pravila donosio učitelj, a sada ih donose djeca pa ih zato i poštuju.

- Prije je svaki učenik sjedio na tačno određenom mjestu, a sada se učenici vesele čestim promjenama mjesta čime se postiže da svi rade sa svima pa se stvara pozitivnija klima u razredu.

- Učenici sada sami koriste i druge izvore znanja (slikovnice, enciklopedije, Internet...). 
- Učenici iz SbS odjeljenja mogu jasno obrazložiti svoj rad, slobodno izražavaju svoje ideje i svoje mišljenje.

- Prije su učenici bili pasivni, a sada su aktivni sudionici u svim aktivnostima.

- Sada se učenici slobodno koriste materijalima iz učionice i mogu odabrati zadatke koje žele raditi.

- «Kada bi mi neko rekao da sada moram raditi po klasičnom programu, teško bih se navikla. Nedostajao bi mi jutarnji/dnevni sastanak, stimulativno okruženje, tematsko planiranje, pozitivna klima u razredu, bolja saradnja $\mathrm{s}$ porodicom, učenje sadržaja kroz igru što motiviše djecu, njihovi izloženi radovi po učionici na što su izrazito ponosni. Djeca vole uređivati učionicu, brinu se o stvarima koje su u učionici, a ne čekaju da zvoni pa da istrče iz učionice - kao prije.» (nastavnica iz Tešnja)

- Novine iz SbS programa motiviraju djecu i kreiraju pozitivniju atmosferu u razredu, a klasika ih uozbilji.

$\mathrm{Na}$ osnovu stavova svih nastavnika, možemo konstatirati elemente koje čine bitno različitim program Step by step od klasičnog osnovnoškolskog programa:

- slobodan izbor aktivnosti - ne robovati rasporedu,

- stimulativno okruženje,

- jutarnji sastanak,

- timski rad,

- rad po različitim nivoima i interesovanjima učenika,

- nove metode,

- partnerstvo sa porodicom.

Pored navednih odgovora, koji najkonkretnije odgovaraju na našu postavljenu hipotezu, navest ćemo i dva komentara nastavnika, koji pokazuju da je primjena metodologije usmjerene na dijete rezultiralo i promjenom unutar nastavnikove osobe.

«Od nastavnika ovaj način rada zahtijeva dosta veću pripremu za rad nego prije, ali se svakako isplati ako svaki dan imate veselu i sretnu djecu spremnu za jako visoke zahtjeve koja jedva čekaju sutrašnji dan i izražavaju žaljenje što dolazi vikend i školski raspust.» (nastavnik iz Tešnja) 
«Četiri godine koristim SbS program i zadovoljna sam postignutim uspjehom učenika. Ovakav način rada je pogodan za svakog ko voli svoj poziv i želi veliki dio svog slobodnog vremena dati svojim učenicima. Sretna sam što sam postigla da je moje odjeljenje postalo jedna jedinstvena, odgovorna, otvorena, iskrena porodica spremna za dalji život, a to je plod mog rada i truda.» (nastavnica iz Tuzle)

Jedan od nastavnika je naveo sljedeće: "U okviru programa Step by step polazi se od uvjerenja da će djeca prihvatiti mnoge različite uloge u učionici:

- Kao mislioci djeca će razmišljati o svojim aktivnostima i napraviti sponu između novog i prethodnog znanja.

- Kao rješavatelji problema djeca će osmisliti alternativna rješenja za prepreke na koje nailaze i probleme sagledati kao mogućnosti za otkrivanje.

- Kao izvjestitelji djeca će razviti vještine i sredstva za komuniciranje o svojim posmatranjima.

- Kao slušaoci djeca će naučiti da potpuno fokusiraju pažnju i postanu aktivni slušaoci.

- Kao komunikatori djeca će formulisati i izražavati vlastite ideje.

- Kao organizatori djeca će planirati vlastito učenje i preuzeti odgovornost za svoje odluke.

- Kao partneri djeca će naučiti da sarađuju i početi da uzimaju u obzir stanovišta drugih osoba.

- Kao prijatelji djeca će naučiti da vjeruju i brinu se o drugima $i$ spoznati da i ona ovise od drugih na isti način." (nastavnik iz Zenice)

"Promjena atmosfere u učionici koja bi postala human, podsticajan i zabavan centar za istraživanje. Učionica treba da predstavlja sigurno mjesto za učenje, okruženje koje olakšava i promovira kooperativan rad, aktivno učenje i samostalnost učenika, gdje prakticiraju demokratski principi i u kojem se sva djeca osjećaju prihvaćeno,sigurno i kompetentno.” (nastavnica iz Tešnja)

"Škole treba da primjenjuju institucionalne i sistematske promjene, mora doći do restruktuiranja administracije, pedagoškog pristupa i školskih objekata kako bi učenici sticali znanja na novi način." (nastavnik iz Tuzle) 
“Stvaranje školske klime u kojoj nastavnici daju podršku jedni drugima i u kojoj učenici učestvuju u donošenju odluka koje se tiču njihovog obrazovanja gradi se osjećaj za školski duh i duh zajednice." (nastavnik iz Tešnja)

"Da bi škole bile u stanju ući u 21. vijek, neophodno im je osigurati moderan nastavni materijal i opremu, poput kompjutera, video rekordera, grafoskopa, kao i sredstva za interaktivnu nastavu." (nastavnik iz Zenice)

"Izrada nastavnog plana i programa razmatra šta je važno da djeca znaju. Podučavanje vještina kritičkog razmišljanja, demokratskog učešća, društvenih vještina i komuniciranja pripremiće djecu za radna mjesta na kojima će funkcionirati kao produktivni i dobro prilagođeni pojedinci." (nastavnica iz Zenice)

"Uključivanje roditelja u svojstvu partnera u školi koristi djeci, porodicama, nastavnicima i cijeloj zajednici. Veze između porodica i škola mogu biti ojačane zajedničkim radom na stvaranju institucija zajednice. Nastavno osoblje bi trebalo pomoći ostvarivanju konstruktivne komunikacije sa roditeljima kada su u pitanju njihova djeca kao individue.I nastavno osoblje treba ohrabriti roditelje da se uključe u dobrovoljni rad u školama.” (nastavnk iz Zenice)

"U opuštenoj atmosferi djeca stiču važne sposobnosti socijalizacije, kao što su sjedenje za stolom, poklanjanje pažnje učitelju, dizanje ruke kada trebaju govoriti, čekanje na red, saradnja u grupi, poštovanje pravila i razvijanje tolerancije prema djeci.

Oni postepeno prelaze sa aktivnosti slobodne igre, kreiranja, slagalica edukativnih igračaka i uskih područja interesa, na bolje struktuiran nastavni program.

Počinjući proces učenja igrom i aktivnostima u kojima uživaju, oni razvijaju stav da je škola sredina u kojoj će biti njegovani i poštovani i gdje će uživati u sticanju novih znanja.

Oni u školu dolaze svježi i motivisani da iskoriste znatiželju i kreativnost, te će vjerovatno ovakav stav zadržati kroz sve godine školovanja ukoliko nastavni program i nastavne metode ostanu inovativne." (nastavnik iz Tuzle)

\section{Stavovovi menadžmenta škole o programu Step by step u odnosu na klasični program}

U cilju dobijanja stavova menadžmenta škole o eventualnoj razlici programa Step by step i klasičnog osnovnoškolskog programa 
anketirali smo direktore, pomoćnike direktora i pedagoge u školama u kojima je sprovedeno istraživanje.

Suština stavova menadžmenta škole o razlici programa Step by step i klasičnog osnovnoškolskog programa je u sljedećem:

- Dosadašnji rad u školama bio je usmjeren ka realizaciji NPP dok je razvoj učenikove ličnosti bio u drugom planu.

- Nastavnik je bio predavač, koji je nudio i zahtijevao isti kvalitet i kvantitet informacija bez obzira na individualne razlike učenika.

- Sada nastavnik primjenjuje nove metode koje neće «gušiti» nego razvijati dječiju kreativnost $\mathrm{i}$ individualne potencijale $\mathrm{i}$ uvažavati razlike.

- Nastavnicima je omogućeno da zajedno sa učenicima kreiraju okruženje, planiraju aktivnosti, da uključuju roditelje, da diferenciraju nastavu i da omoguće svakom djetetu da razvije svoje pune potencijale.

- Učenici iz SbS odjeljenja se dogovaraju, slobodno iznose svoje mišljenje, uvažavaju tuđe, donose odluke koje su dobre za sve učenike, a ne samo za pojedinca. Ne zadovoljavaju se klasičnim časovima obrade gdje dobivaju gotova znanja jer žele da učestvuju, zahtijevaju objašnjenja i vole da objasne kako su riješili neki problem.

- Na časovima učenici samostalno sastavljaju zadatke, postavljaju pitanja i istražuju. Vole da rade u timu, da traže mišljenje drugih, da ukazuju na greške i svoje i drugih u timu.

- Zbog veće individualizacije nastave djeca su osposobljenija da samostalno uče i pri tome koriste sve resurse. Učenici uvažavaju tuđe mišljenje i kada se s tim mišljenjem ne slažu ne nameću svoja rješenja.

- Više su razvijenije komunikacijske vještine kod učenika iz SbS odjeljenja nego kod učenika iz klasičnih odjeljenja.

- Znanja koja učenici stiču radeći po SbS metodama su šira, trajnija zbog samog načina učenja.

- Od učenika se ne zahtijeva da samo memorira i reproducira naučeno nego i da ga primjenjuje.

- Stjecanje znanja je rezultat radoznalosti i aktivnosti djece.

- U klasičnoj nastavi djeca su plašljiva, neka ne žele da dolaze u školu, nerado izvršavaju školske obaveze, osjećaju se umorno 
dok u SbS odjeljenjima djeca rado dolaze u školu, nisu plašljiva i vole da učestvuju u školskim aktivnostima.

- «Ne postoji dijete koje ne voli školu ako škola voli njega.» Uspostavljeno je partnerstvo. Nastavnici su shvatili da su im roditelji bogat resurs znanja, da im mogu pomoći u mnogim školskim aktivnostima. Djeca se više ne plaše posjete roditelja školi nego sa radošću očekuju njihovo prisustvo u školi.

Stavove menadžmenta smo sortirali po određenim segmentima i uporedili program Step by step i klasični osnovnoškolski program.

Tabela 8: Stavovi menadžemnta o odnosu Step by step programa $i$ klasičnog programa

\begin{tabular}{|c|c|c|}
\hline Segment & Klasika & SbS \\
\hline Usmjerenost na & Prosječnog učenika & $\begin{array}{l}\text { Svakog učenika - individualizirani } \\
\text { pristup }\end{array}$ \\
\hline Oblici rada & $\begin{array}{ll}\text { Dominira frontalni } \\
\mathrm{rad}\end{array}$ & $\begin{array}{l}\text { Balans između rada u velikoj grupi, } \\
\text { malim grupama, parovima } \\
\text { individualno }\end{array}$ \\
\hline Metode rada & $\begin{array}{l}\text { Dominira } \\
\text { predavanje }\end{array}$ & $\begin{array}{lr}\text { Istraživanje, } & \text { eksperiment, debate, } \\
\text { demonstriranje, rješavanje problema... }\end{array}$ \\
\hline Prostor & $\begin{array}{ll}\text { Učenici } & \text { sjede } \\
\text { klupama } & \end{array}$ & $\begin{array}{l}\text { Stimulativno okruženje prilagođeno } \\
\text { aktivnom učenju }\end{array}$ \\
\hline Planiranje & Po predmetima & Integrirano/ tematsko \\
\hline Ocjenjivanje & Usmeno i pismeno & Kontinuirano \\
\hline \begin{tabular}{|l|} 
Dnevni \\
raspored
\end{tabular} & $\begin{array}{lr}\text { Časovni } & \text { sistem } \\
\left(\begin{array}{l}\text { (uvod, } \\
\text { zaključak) }\end{array}\right. & \text { razrada, } \\
\end{array}$ & Balansirane aktivnosti \\
\hline \begin{tabular}{|l|} 
Uloga \\
nastavnika
\end{tabular} & Predaje, podučava & $\begin{array}{l}\text { Facilitira, modeluje, demonstrira, } \\
\text { donosi odluke, prati i dokumentuje }\end{array}$ \\
\hline Uloga učenika & Pasivan slušalac & Aktivan, donosi odluke, ima izbor \\
\hline Roditelji & Saradnja & Partnerstvo \\
\hline
\end{tabular}

\section{ZAKLJUČAK}

Rezultati t-testa su pokazali da ne postoji statistički značajna razlika u uspjehu iz Matematike učenika koji rade po programu Step by Step i učenika koji rade po klasičnom programu, jer je $\mathrm{t}=1,756$, a $\mathrm{p}=, 081$. Također, rezultati t-testa su pokazali da postoji statistički značajna razlika u uspjehu iz Proride i društva učenika koji rade po 
programu Step by Step i učenika koji rade po klasičnom programu, statistički značajno je bolji uspjeh učenika koji rade po programu Step by Step, jer je $\mathrm{t}=3,120$, a $\mathrm{p}=, 002$.

Rezultati istraživanja su pokazali da su učenici koji nastavu pohađaju po metodologiji usmjerenoj na dijete dosta slobodniji i vještiji u komunikaciji, samopouzdaniji, jasno izražavaju svoje mišljenje i uvažavaju i poštuju druge u grupi te da izjavljuju da roditeljima ispričaju sve šta su radili u školi jer i oni to moraju znati kako bi im pomogli u nečemu što im slabo ide, i time se bitno razlikuju od učenika koji se školuju po klasičnom programu.

Rezultati istraživanja su pokazali u odgovorima na sva pitanja iz ankete da postoje značajne razlike u odgovorima roditelja, čak dijametralno suprotne efekte programa konstatiraju: da djeca koja rade po «klasičnom» programu uglavnom govore o tome šta su učili novo, šta su dobili u školi, dok djeca koja rade po Step by step programu govore o načinu rada - kako su učili o nečemu - i traže od roditelja neke podatke koji im trebaju. «Koriste nas kao izvor informacija»; roditelji djece koja rade po «klasičnom» programu smatraju da se njihova djeca u školi ne uče donošenje odluka, kritičkom mišljenju, samostalnosti i uvažavanju drugih, ali nisu naveli primjere, dok roditelji djece koja rade po Step by step programu smatraju da njihova djeca: uče donositi odluke (vidio sam kada sama odlučuju na koji način će predstaviti zadatak, ko će šta raditi u grupi i sl.), učestvuju u donošenju pravila ponašanja u razredu, diskutuju o problemima, daju svoje prijedloge, slobodno iznose svoje mišljenje, svoje stavove, samostalno rade zadatke kod kuće, traže podatke po knjigama, novinama, internetu uvažavaju jedni druge, nemaju predrasuda, druže se sa svima.

Rezultati istraživanja su pokazali u odgovorima nastavnika na sva pitanja iz ankete bitnu razliku Step by step i klasičnog programa te izdvajaju značajno boljim program Step by step po svim elementima: pozitivno je izmijenjen pristup radu nastavnika, osnažena je uloga roditelja u planiranju, programiranju i izvođenju nastavnih i vannastavnih aktivnosti, obrazovni efekti nastave su veći, ustanovljena je veća razvijenost, socijalnih, emocionalnih i interpersonalnih kompetencija učenika u stimulativnoj razrednonastavnoj klimi koju je bitno odredio i program svojim sveukupnim karakteristikama. 
Rezultati istraživanja su pokazali u odgovorima direktora, pomoćnika direktora i pedagoga u svim školama i na sva pitanja iz ankete bitnu razliku Step by step i klasičnog programa te izdvajaju značajno boljim program Step by step po svim elementima: naglašavaju izmijenjenu uloga nastavnika $i$ učenika $i$ njihovih roditelja, daju prednost Step by step programu u više elemenata usmjerenosti programa, oblicima i metodama rada, prostoru za rad, planiranju, ocjenjivanju, dnevnom rasporedu aktivnosti, ulozi nastavnika, učenika i roditelja.

Rezultati ovog istraživanja daju jasne smjernice kreatorima obrazovne politike koji bi u svim reformskim zahvatima prije svega morali uvažavati učenike i zadovoljavanje njihovih razvojnih potreba. Naglašava se značenje takozvanog «učeniku usmjerenog obrazovanja» i potreba za uvažavanjem zakonitosti ljudskog razvoja kao i rezultata mnoštva istraživanja u području učenja, ljudskog razvoja i motivacije pri kreiranju obrazovne politike.

Nadamo se da ovi rezultati mogu poslužiti kao orijentir za buduća promišljanja planiranja programa usmjerenih na dijete $\mathrm{i}$ njihove procjene. Smatramo da bi za potpunije i znanstveno utemeljenije donošenje sudova o obrazovnim efektima programa Step by step i klasičnog osnovnoškolskog programa trebalo istraživanjem pratiti učenike kroz cijelo osnovnoškolsko obrazovanje.

\section{LITERATURA}

1. Bijeli papir, Zajednička strategija za modernizaciju osnovnog $i$ općeg srednjeg obrazovanja u Bosni i Hercegovini (dokument izradile obrazovne vlasti u Bosni i Hercegovini uz pomoć ECTAER programa koji je finansirala EU), oktobar, 2003.

2. Borojević, S. (1974): Metodologija eksperimentalnog rada, Radinički univerzitet "Radivoj Ćirpanov, Novi Sad

3. Bratanić, M. (2002): Paradoks odgoja, Hrvatska sveučilišna nagrada, Zagreb

4. Bredkamp, S. (1996): Kako djecu odgajati, Educa, Zagreb

5. Brkić, M., Kundačina, M. (2003): Statistika u istraživanju odgoja i obrazovanja, Jela educa d.o.o. Sarajevo, Mostar - Sarajevo 
6. Burke Walsh, Kate (2000): Stvaranje učionica u kojima dijete ima centralnu ulogu (6-7 godina), Centar za obrazovne inicijative «STEP BY STEP«, Sarajevo

7. Domović, V. (2003): Školsko ozračje i učinkovitost škole, Naklada Slap, Jastrebarsko

8. Dryden, G. i Vos, J. (2001): Revolucija u učenju: kako promijeniti načina na koji svijet uči. Educa, Zagreb

9. Glasser, W. (1994): Kvalitetna škola, Educa, Zagreb

10. Gossen, D. i Anderson, J. (1996): Stvaranje uvjeta za kvalitetne škole. Alinea, Zagreb

11. Grgin, T. (2001): Školsko ocjenjivanje znanja, Naklada Slap, Jastrebarsko

12. Juul, J. (1996): Vaše kompetentno dijete, Zagreb

13. Krneta, LJ (2000), Faktori školskog uspjeha, Banjaluka Kompani, Banjaluka

14. Meyer, H. (2005): Što je dobra nastava, Erudita, Zagreb

15. Milić, S.S. (2002): Individualizovani pristup u vaspitnoobrazovnom procesu, Pedagoški centar Crne Gore, Podgorica

16. Miller, B. (2001): Kako ostvariti uspješnu komunikaciju s učenicima, Priručnik za nastavnike, Sarajevo

17. Osmić, I. (2001): Komunikacija i interakcija u nastavnom procesu, GRIN Gračanica

18. Radonjić, S. (1966): Mjerenje sposobnosti učenja, Zbornik Filozofskog fakulteta, knjiga 9/2, Beograd

19. Richard, K. \& Radford, J. (1978): Individualne razlike, Nolit, Beograd

20. Slatina, M. (2004): Od individue do ličnosti - Uvođenje u teoriju konfluentnog obrazovanja

21. Stoll, L. \& Fink, D. (2000): Mijenjajmo naše škole, Educa, Zagreb

22. Šefer, J. (2000): Kreativnost dece: problemi vrednovanja, Institut za pedagoška istraživanja, Beograd

23. Šestanović, M. (2000): Zločin nad psihičkim integritetom djece, Institut za istraživanje zločina protiv čovječnosti i međunarodnog prava, Sarajevo 
PROF. DR. REFIK ĆATIĆ, P.H.D.

VAHDETA ĆATIĆ. M.A.

\section{EXXAMINING OF EDUCATIONAL EFFECTS OF «STEP BY STEP» PROGRAMME}

SUMMARY

Aim of this research was a try to analyze educational effects of «step by step» programme and compare them with effects of classical primary school syllabus with primary school fourth graders.

This research has shown no important difference in educational effects between pupils who attend child focused methodology classes and pupils who attend "classical» classes in subjects: Maths and Science and society.

A significant difference has been ascertained in pleasure and positive attitudes towards school with children who attend child focused methodology classes and with their parents.

The pupils that attend child focused methodology classes are freer, they communicate skilfully, respecting rules of communication, they are more self confident in expressing their opinion, making decisions, they are capable of team work and they tolerate differences.

The results of this research are encouraging in child's and parent's view, because planning of lessons adapted to child' development and needs indeed creates more positive and stimulating atmosphere in the class. 
الأستاذ الدكتور رفيق تتثاتينت م. وحدنا تثانيش

اختبار الآثار التعليمية لبرنامج "خطوة بخطوة"

الملخص

الهدف من هذا البحث هو محاولة إثبات الآثار التعليمية لبرنامج "خطوة بخطوة"

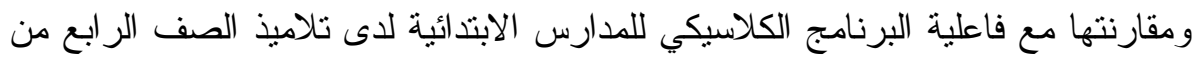
الددرسة الابندائية.

لقد أثتبت البحث أنه لا فرق يُنْكَرُ من ناحية الآثار التعليمية بين منهجية موجهة للطفل

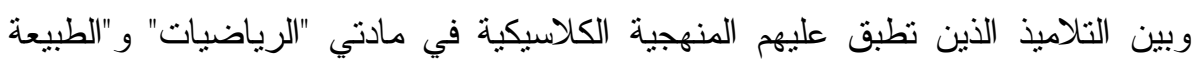
و المجتمع". لقد تم إثبات فروق ملحوظة في الرضا و التعامل الأكثر إيجابيةً تجاه المدرسة لدى تلاميذ وذَوِيهم الذين تطبق عليهم المنهجية الموجهة.

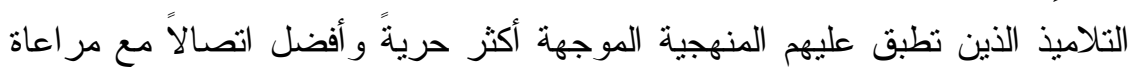

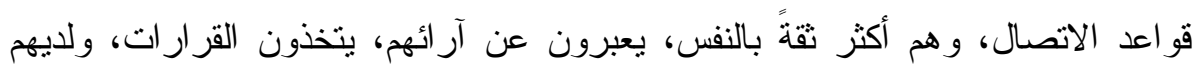

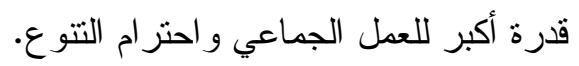

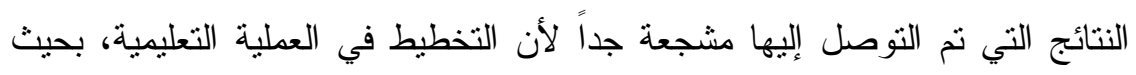

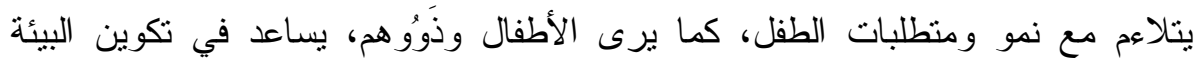
الإيجابية و الحافزة في الصف و أثناء العملية التعليمية. 